\title{
Sporadic hemangioblastoma of the filum terminale: Case report and review of literature
}

\author{
Prashant S. Gade, Vernon Velho, Harish Naik, Laxmikant Bhople \\ Department of Neurosurgery, Grant Government Medical College, Mumbai, INDIA
}

\begin{abstract}
Hemangioblatomas are low grade, highly vascular tumors usually associated with VHL syndrome and most commonly occurs in the cerebellum. They very rarely occur in the spinal nerve roots and an origin in the filum terminale is exceptionl. A 47 year old man presented with low back pain, paresthesias and stiffness of the both lower limbs. He also had urinary retention and constipation. MRI showed an enhancing mass at the L5 vertebral level with multiple dilated and tortuous vessels at both poles of the tumor. Digital subtraction angiogram showed the tumor to be supplied by the anterior spinal artery and dural branches of lumbar arteries. At surgery, a well-defined tumor with orange red hue was found to be arising from the filum terminale. The tumor was excised en bloc. Histopathological examination showed hemangioblastoma which was confirmed with immunohistochemistry. Clinical symptoms improved significantly after surgery. A sporadic hemangioblastoma arising from the filum terminale should be considered as a rare cause of back pain and sciatica. Total excision of the tumor usually cures the patient.
\end{abstract}

Key words: Cauda equina, Extramedullary, Filum terminale Hemangioblastoma Sporadic, von Hippel-Lindau syndrome

Abbreviations: VHL - von Hippel-Lindau; CT - Computed Tomography; MRI -

Magnetic resonance Imaging; WHO - World Health Organization

\section{Introduction}

Tumors of the cauda equina are uncommon and those arising from the filum terminale are even rarer. Most common tumors affecting this region include ependymoma, schwannoma, neurofibroma and meningioma. Hemangioblastoma is a rare occurrence at this site, most of them affecting the cervical or thoracic spine. Hemangioblastoma of the filum terminale is extremely rare and only a few cases are reported in the literature.

Here we describe a rare case of hemangioblastoma arising from filum terminale, diagnosed in a patient without clinical criteria of von Hippel-Lindau (VHL) 
syndrome and briefly review the relevant literature.

\section{Case report}

A 47 year old male presented with low back pain radiating to both lower limbs since 5 years. Pain was insidious in onset, gradually progressive, ill defined, moderate in intensity and increased in recumbent position. Since last 2 years pain increased in intensity especially at night times and became more continuous. He also developed stiffness and paresthesias in both lower limbs. He had to strain to pass urine and also had constipation. Family history was unremarkable. On examination, lower limbs were spastic. There was no motor weakness or sensory deficit. Screening for VHL syndrome was negative.

Magnetic resonance imaging (MRI) of the Lumbosacral region revealed a well-defined intradural lesion at the level of sacralised L5 vertebra. Tumor was isointense on T1weighted and hyperintense on T2-weighted images with intense contrast enhancement and numerous flow voids within. Multiple dilated, tortuous vessels are seen in the intradural extramedullary compartment extending from D8 to L5 level (Figure 1). Spinal angiogram showed highly vascular tumor at L5 pedicular level supplied predominantly by anterior spinal artery. Other feeders to the tumor were the dural branches from bilateral lumbar arteries.

Patient underwent L4 to S1 laminectomy through midline incision. Thecal sac was found to be expanded and thinned out. Durotomy revealed well defined, firm, lobulated mass with orange-red hue. There were dilated venous channels at both poles of the tumor. Tumor was arising from the filum terminale and displacing the nerve roots of the cauda equina laterally. Tumor was dissected circumferentially, preserving all nerve roots of the cauda equina and removed in an en bloc manner. The dilated venous channels which were entering and leaving the tumor capsule were coagulated and sharply divided (Figure 2).

Histopathology showed a highly vascular tumor composed of vascular channels of various sizes with intervening stromal cells. There were foci of hemorrhage and some vessels were thrombosed. No atypias or mitotic figures were found (Figure 3). Histopathological diagnosis of hemangioblastoma (reticular variant) was made and confirmed with immunohistochemistry.

Immunohistochemical stains showed positivity for CD31, CD34 in endothelial cells while stromal cells were neagative for CD34. Stromal cells were positive for neuron specific enolase but negative for glial fibrillary acidic protein. S-100, epithelial membrane antigen and cytokeratin stains were negative.

Postoperatively, he had no new neurological deficit. At 1 month follow-up, he reported significant pain relief with no need for further analgesic. Postoperative MRI confirmed the complete excision of the tumor.

\section{Discussion}

Hemangioblastomas are benign, slow growing, highly vascular tumors and considered as grade $\mathrm{I}$ in the WHO classification of CNS tumors. 
Hemangioblastomas account for 1.6 to $2.1 \%$ of all spinal cord tumors. (3) These tumors may occur sporadically (67-75\%) or as a part of multisystem involvement in VHL syndrome (25-33\%). (3) Majority of these lesions are intramedullary, affecting all spinal levels and all compartments. Extramedullary disease is relatively uncommon and represents approximately one fifth of all spinal cord hemangioblastomas. (2) The incidence of isolated hemangioblastomas of the cauda equina is unclear. Our literature review revealed 26 previously reported cases of sporadic hemangioblastoma occurring in the cauda equina, out of which 15 are described to be arising from the filum terminale. (Table 1)

TABLE 1

Reported cases of sporadic filum terminale hemangioblastomas ${ }^{*}$

\begin{tabular}{|c|c|c|c|c|c|c|c|c|}
\hline & $\begin{array}{l}\text { Authors \& } \\
\text { Year }\end{array}$ & $\begin{array}{l}\text { Age } \\
\text { (yrs) }\end{array}$ & Sex & $\begin{array}{l}\text { Spinal } \\
\text { level }\end{array}$ & Symptoms & MR imaging & $\begin{array}{c}\text { Angiogra } \\
\text { phy }\end{array}$ & $\begin{array}{l}\text { Treatment \& } \\
\text { outcome }\end{array}$ \\
\hline 1. & $\begin{array}{l}\text { Wyburn- } \\
\text { Mason, } 1943\end{array}$ & 25 & $\mathrm{~F}$ & L2-S2 & Radicular pain & NA & NA & $\begin{array}{l}\text { surgery, } \\
\text { improved }\end{array}$ \\
\hline 2. & $\begin{array}{l}\text { Norstrom et } \\
\text { al., } 1961\end{array}$ & \multicolumn{2}{|c|}{ NR } & NR & NR & NA & NA & NR \\
\hline 3. & $\begin{array}{l}\text { Sloof et al., } \\
1964\end{array}$ & 51 & $\mathrm{M}$ & L4-S1 & NR & NA & NA & $\begin{array}{l}\text { surgery, } \\
\text { outcome NR }\end{array}$ \\
\hline 4. & $\begin{array}{l}\text { Wolbers et al., } \\
1985\end{array}$ & 36 & M & L1 & $\begin{array}{l}\text { Radicular \& Lumbar pain, } \\
\text { cauda equina syndrome }\end{array}$ & NA, diagnosis by CT & NA & $\begin{array}{l}\text { surgery, } \\
\text { improved }\end{array}$ \\
\hline 5. & $\begin{array}{l}\text { Silverman et } \\
\text { al., } 1986\end{array}$ & 66 & M & $\mathrm{L} 2$ & $\begin{array}{l}\text { Back \& leg pain, partial } \\
\text { cauda equina syndrome }\end{array}$ & $\begin{array}{l}\text { NA, diagnosis based on } \\
\text { myelogram }\end{array}$ & NA & $\begin{array}{l}\text { surgery, } \\
\text { improved }\end{array}$ \\
\hline 6. & $\begin{array}{l}\text { Tibbs et al., } \\
1999\end{array}$ & 35 & M & L2-L3 & $\begin{array}{l}\text { Lumbar pain, worse on } \\
\text { sitting }\end{array}$ & $\begin{array}{l}\text { Enhancing mass with } \\
\text { serpentine flow voids }\end{array}$ & NA & $\begin{array}{l}\text { surgery, } \\
\text { improved }\end{array}$ \\
\hline 7. & $\begin{array}{l}\text { Arbelaez et al, } \\
1999\end{array}$ & 73 & $\mathrm{M}$ & L1-L2 & Lumbar \& radicular pain & $\begin{array}{l}\text { Enhancing mass with } \\
\text { serpentine flow voids }\end{array}$ & NA & $\begin{array}{l}\text { surgery, } \\
\text { improved }\end{array}$ \\
\hline 8. & $\begin{array}{l}\text { Farnetti et al., } \\
2001\end{array}$ & 57 & $\mathrm{M}$ & L4 & $\begin{array}{l}\text { Lumbar \& radicular pain, } \\
\text { worse while recumbent }\end{array}$ & $\begin{array}{l}\text { Enhancing mass with } \\
\text { serpentine flow voids }\end{array}$ & NA & $\begin{array}{l}\text { surgery, } \\
\text { improved }\end{array}$ \\
\hline 9. & $\begin{array}{l}\text { Biondi et al., } \\
2005\end{array}$ & 61 & $\mathrm{M}$ & L3 & $\begin{array}{l}\text { Motor \& sensory } \\
\text { disturbances }\end{array}$ & $\begin{array}{l}\text { Enhancing mass with } \\
\text { serpentine flow voids }\end{array}$ & yes & $\begin{array}{l}\text { surgery, } \\
\text { unknown }\end{array}$ \\
\hline 10. & & NR & $\mathrm{M}$ & NR & Only sensory disturbances & $\begin{array}{l}\text { Enhancing mass with } \\
\text { serpentine flow voids }\end{array}$ & yes & $\begin{array}{l}\text { surgery, } \\
\text { unknown }\end{array}$ \\
\hline 11. & \begin{tabular}{|l|} 
Nadkarni et al., \\
2006
\end{tabular} & 52 & M & L2-L3 & $\begin{array}{l}\text { Lumbar pain, paresthesias, } \\
\text { sphincter disturbances }\end{array}$ & $\begin{array}{l}\text { Enhancing mass with } \\
\text { serpentine flow voids }\end{array}$ & yes & $\begin{array}{l}\text { surgery, } \\
\text { improved }\end{array}$ \\
\hline 12. & $\begin{array}{l}\text { Ortega- } \\
\text { Martinez et al., } \\
2007\end{array}$ & 41 & $\mathrm{~F}$ & $\mathrm{~L} 3 \& \mathrm{~S} 1$ & $\begin{array}{l}\text { Lumbar pain, worse in } \\
\text { recumbent,better after } \\
\text { abortion }\end{array}$ & $\begin{array}{l}\text { Iso- \& hyperintense } \\
\text { masses with flow voids, } \\
\text { no contrast }\end{array}$ & yes & $\begin{array}{l}\text { surgery, minimal } \\
\text { hypesthesia }\end{array}$ \\
\hline 13. & $\begin{array}{l}\text { Ciapetta et al., } \\
2007\end{array}$ & 62 & $\mathrm{~F}$ & L2-L3 & Lumbar pain, paresthesias & $\begin{array}{l}\text { Enhancing mass, no flow } \\
\text { voids }\end{array}$ & no & $\begin{array}{l}\text { surgery, } \\
\text { improved }\end{array}$ \\
\hline 14. & $\begin{array}{l}\text { Wong et al., } \\
2007\end{array}$ & 64 & M & $\mathrm{L} 4$ & Lumbar pain & $\begin{array}{l}\text { Enhancing mass with } \\
\text { serpentine flow voids }\end{array}$ & yes & $\begin{array}{l}\text { surgery, transient } \\
\text { urinary incontinence }\end{array}$ \\
\hline 15. & $\begin{array}{l}\text { Sergides et al., } \\
2009\end{array}$ & 75 & M & L3 & Asymptomatic, incidental & $\begin{array}{l}\text { Enhancing mass, no flow } \\
\text { voids }\end{array}$ & no & $\begin{array}{l}\text { surgery, } \\
\text { no complication }\end{array}$ \\
\hline 16. & Present case & & M & L5 & $\begin{array}{l}\text { Lumbar pain, paresthesias, } \\
\text { sphincter disturbances }\end{array}$ & $\begin{array}{l}\text { Enhancing mass with } \\
\text { serpentine flow voids }\end{array}$ & yes & $\begin{array}{l}\text { surgery, } \\
\text { improved }\end{array}$ \\
\hline
\end{tabular}




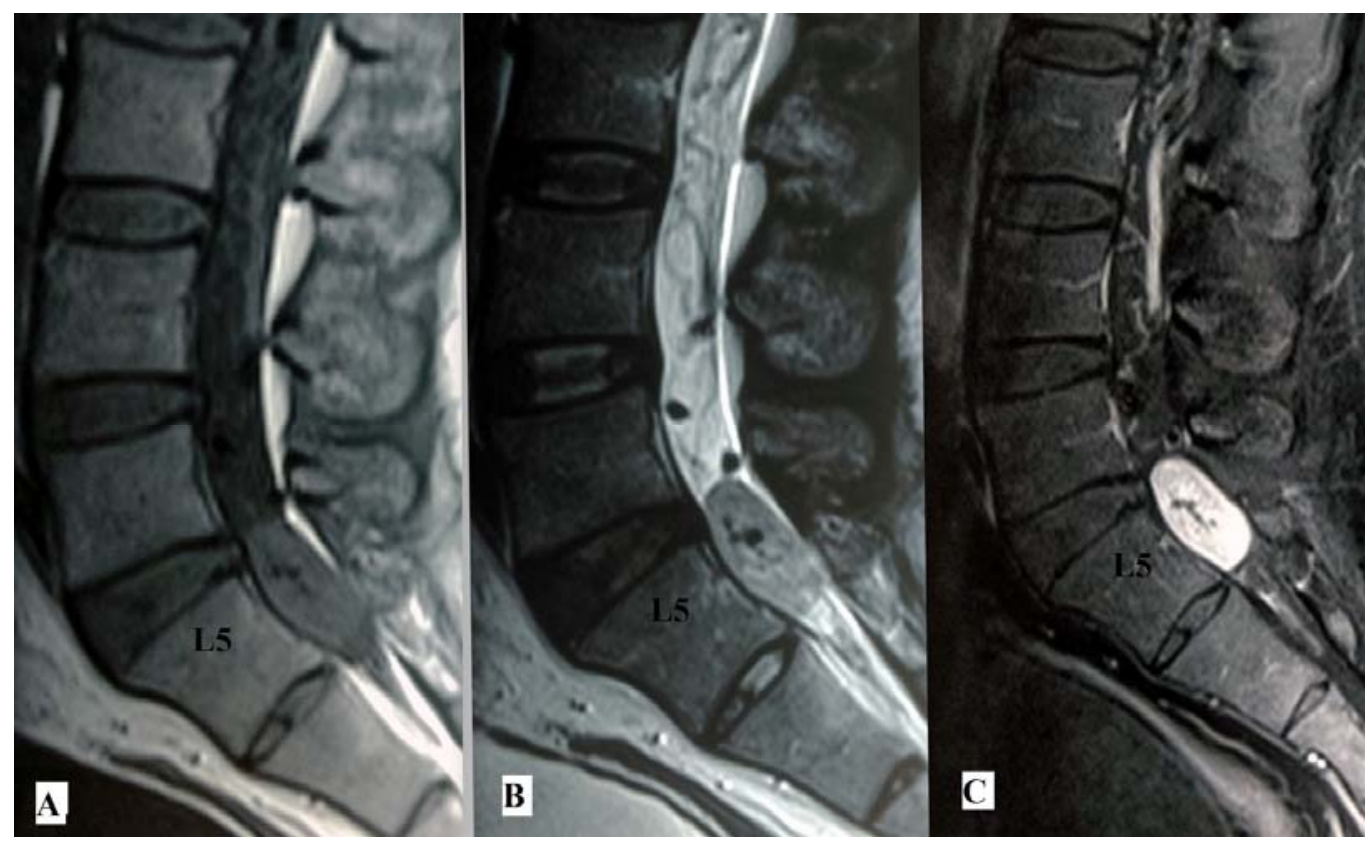

Figure 1 - Magnetic resonance imaging shows intradural extramedullary mass at the level of sacralised L5 vertebra. Mass appears isointense on T1 weighted images (A) and hyperintense with flow voids on T2 weighted images (B). T1 weighted contrast images shows enhancing mass with tortuous feeding vessels (C)

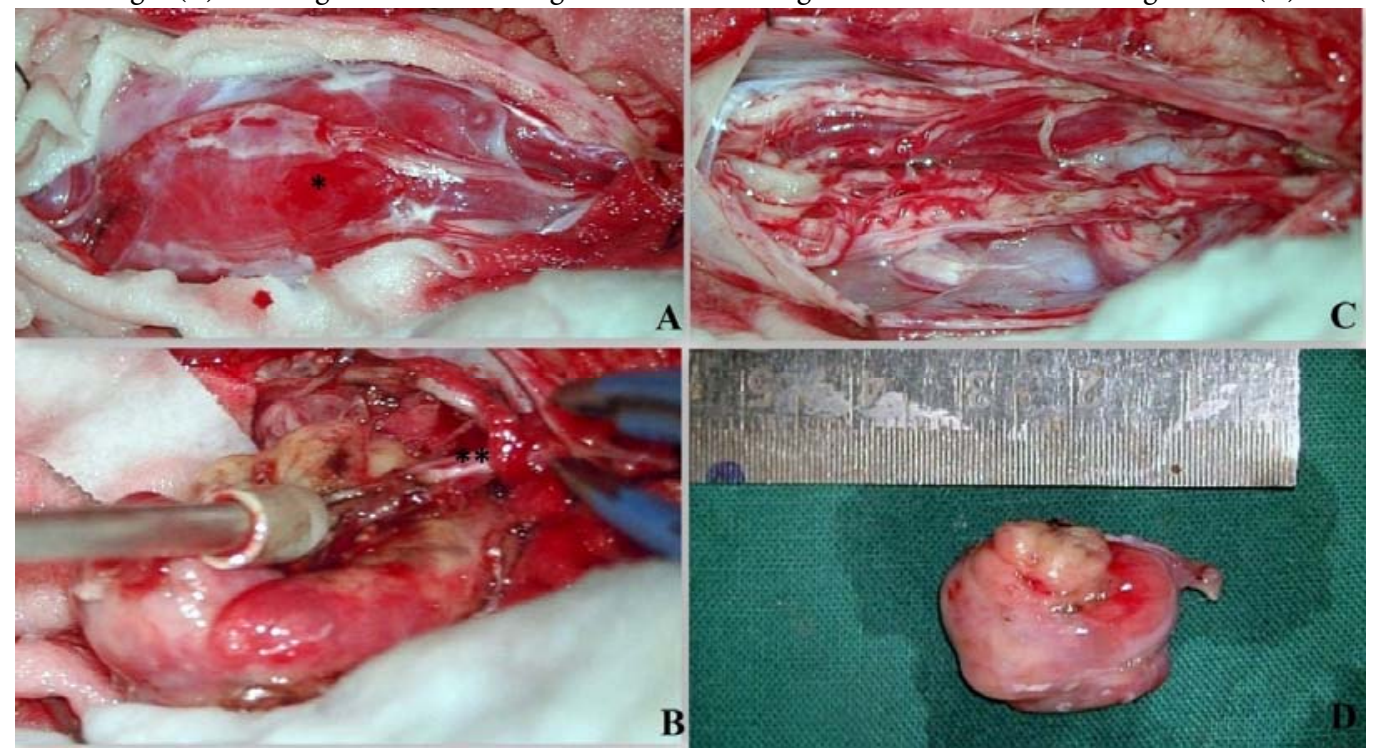

Figure 2 - Intraoperative photographs showing the surgical steps.(A) Duratomy exposed a firm, lobulated, reddish tumor $\left.{ }^{*}\right)$ with dilated and tortuous vessels on the surface.(B) Tumor was originating from the filum terminale $\left.{ }^{* \star}\right)$.(C)Final step showing en bloc resection of the tumor.(D)Surgically excised specimen of hemangioblastoma (D) 


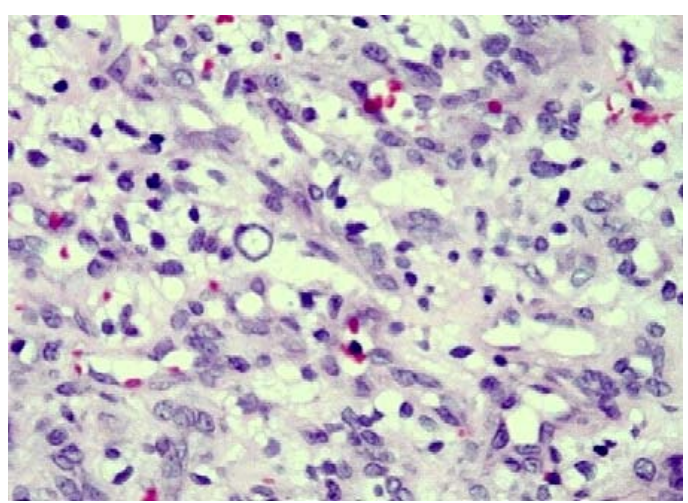

Figure 3 - Histological section shows a highly vascular tumor composed of vascular channels of varying sizes with intervening vacuolated stromal cell (Haematoxylin and eosin, original magnification $\mathrm{x} 300$ )

Filum terminale hemangioblastomas can remain asymptomatic for several years. However as they grow in size, they may cause compression of the surrounding neural structures and cause symptoms. Most common symptoms are progressive low back pain, radiating to lower limbs and weakness of the lower limbs. Most of the previously reported patients have radicular symptoms except the patient reported by Tibbs et al. (7) With further increase in size it may also cause cauda equina syndrome.

On MRI of the lumbosacral region, hemangioblastoma appears isointense on T1W and hyperintense on T2W. The hyperintensity is characteristically heterogenous due to the flow voids resulting from high vascularity. Schwannoma, on the other hand, shows a uniform homogenous hyperintesity on $\mathrm{T} 2 \mathrm{~W}$, thus differentiating it from hemangioblastoma. On contrast study, there is marked tumoral enhancement; however, the patterns do not help in differentiating it from other neurogenic tumors. The most characteristic finding on MRI is serpentine flow voids of tortuous and convulated vessels (4) which was seen in our case and was also reported by most other authors. Spinal angiography is the gold standard in the diagnosis of spinal vascular malformations. It is more sensitive and specific in differentiating solid tumor from vascular malformations. Angiography can better define the lesion, provides information about feeding arteries/venous drainage and help in the preoperative embolization. However preoperative embolization was not considered in our case.

Total surgical resection is the treatment of choice. (5) These tumors should be dissected circumferentially and removed en bloc; intralesional debulking should not be done as it may lead to profuse bleeding. Incomplete resection has been associated with a high rate of recurrence. Radiosurgery has been used in cases of residual tumor after subtotal tumor excision. (1)

Histopathologically, hemangioblastomas are benign lesions, partly cystic, consisting of stromal cells and endothelium-lined vascular channels. Two histological variants are described; reticular and cellular. In reticular type, stromal cells are evenly distributed around the vascular network while in cellular variant, they are arranged in larger sheets or clusters. On immunohistochemistry, the endothelial cells stain positive for CD34 whereas stromal cells stain negative for the same. (6) Immunohistochemistry is also helpful in differentiating it from other tumors. Absence of S-1oo, epithelial membrane antigen and cytokeratin rules out the 
schwannoma and meningioma. Stromal cell positivity for neuron specific enolase along with absent glial fibrillary acidic protein rules out hemangiopericytoma. Inhibin alpha is useful for differentiating hemangioblastoma from other vascular tumors such as capillary hemangioma.

\section{Conclusion}

The present case report shows the rare occurrence of intradural extramedullary spinal hemangioblastoma originating from the filum terminale, not associated with VHL syndrome. Spinal angiography remains the gold standard for the diagnosis. Based on neuroimaging, tumor associated with serpentine flow voids of tortuous and convulated vessels appeared to be the best diagnostic indicator. In addition to the histopathological examination, immunohistochemical stains are needed to make the diagnosis. Complete resection of the tumor is considered as the treatment of choice, as recurrence is common with incomplete excision. Filum terminale hemangioblastoma even though rare should be included in the differential diagnoses of the tumors of the cauda equina.

\section{Correspondence}

Dr. Prashant S. Gade

MBBS, DNB (Gen Surg), MCh, DNB (Neurosurg)

Senior resident, Department of Neurosurgery,

Grant Government Medical College, Mumbai

dr.prashantgade@gmail.com

Mob. No. 9890129901

\section{References}

1. Blaty D, Malos M, Palmrose T, McGirr S: Sporadic intradural extramedullary hemangioblastoma of the cauda equina: case report and literature review. World Neurosurg 109: 436-441, 2018

2. Brisman JL, Borges LF, Olgilvy CS: Extramedullary hemangioblastoma of the conus medullaris. Acta Neurochir (Wien) 142(9): 1059-1062, 2000

3. Browne TR, Adams RD, Roberson GH: Hemangioblastoma of the spinal cord. Review and report of five cases. Arch Neurol 33: 435-441, 1976

4. Kunihiro N, Takami T, Yamagata T, Tsuyuguchi N, Ohata K: Spinal hemangioblastoma of the cauda equina origin not associated with von Hippel-Lindau Syndromecase report. Neurol Med Chir (Tokyo) 51(10): 732-735, 2011

5. Nadkarni TD, Menon RK, Desai KI, Goel A: Hemangioblastoma of the filum terminale. J Clin Neurosci 13: 285-288, 2006

6. Taniguchi S, Ogikubo O, Nakamura T, Yamagishi I, Hayakawa K, Otsuka $\mathrm{T}$, Katoh $\mathrm{T}$ : A rare case of extramedullary-intradural hemangioblastoma in the thoracic spine. Spine 34(26): E969-E972, 2009

7. Tibbs RE Jr, Harkey HL, Raila FA: Hemangioblastoma of the filum terminale: case report. Neurosurgery 44(1): 221-223, 1999 